\title{
Pengaruh Kinerja Keuangan dan Keputusan Investasi Terhadap Nilai Perusahaan Dengan Kebijakan Dividen Sebagai Variabel Intervening
}

\author{
Dea Agustin Adrianingtyas ${ }^{1 *}$, Agus Sucipto ${ }^{2}$ \\ ${ }^{12}$ Fakultas Ekonomi UIN Maulana Malik Ibrahim Malang \\ 1Email: adrianingtyasd@gmail.com, ${ }^{2}$ Email: suga_cipto@yahoo.co.id \\ *Corresponding author
}

\begin{abstract}
This study aims to prove the effect of financial performance and investment decisions on firm value with dividend policy as an intervening variable. The research method uses a quantitative approach with financial report documentation on chemical sector companies listed on the Indonesia Stock Exchange for the period 2013-2017. Data analysis using classical assumption test and path analysis. The results showed that financial performance has a negative and significant effect on firm value, investment decisions and dividend policy does not affect company value, financial performance and investment decisions have a positive and significant effect on dividend policy, and partially financial performance and investment decisions have an influence on value company with dividend policy as an intervening variable.
\end{abstract}

Keywords: Financial Performance; Investment Decisions; Firm Value; Dividend Policy

\begin{abstract}
Abstrak. Penelitian ini bertujuan untuk membuktikan pengaruh kinerja keuangan dan keputusan investasi terhadap nilai perusahaan dengan kebijakan dividen sebagai variabel intervening. Metode penelitian menggunakan pendekatan kuantitatif dengan dokumentasi laporan keuangan pada perusahaan sektor kimia yang terdaftar di BEI periode 2013-2017. Analisis data menggunakan uji asumsi klasik dan analisis jalur. Hasil penelitian menunjukan bahwa kinerja keuangan berpengaruh negatif dan signifikan terhadap nilai perusahaan, keputusan investasi dan kebijakan dividen tidak berpengaruh terhadap nilai perusahaan, kinerja keuangan dan keputusan investasi berpengaruh positif dan signifikan terhadap kebijakan dividen, dan secara parsial kinerja keuangan dan keputusan investasi memiliki pengaruh terhadap nilai perusahaan dengan kebijakan dividen sebagai variabel intervening.
\end{abstract}

Kata Kunci: Kinerja Keuangan; Keputusan Investasi; Nilai Perusahaan; Kebijakan Dividen

\section{PENDAHULUAN}

Indonesia termasuk salah satu negara yang berkembang di dunia, hal ini terbukti dengan adanya pembangunan di segala bidang termasuk pembangunan sektor ekonomi. Perekonomian di Indonesia yang semakin membaik menyebabkan timbulnya gairah bagi para pengusaha untuk mengelola perusahaannya di Indonesia.

Berdirinya sebuah perusahaan harus memiliki tujuan yang jelas. Ada beberapa hal yang mengemukakan tujuan dari berdirinya sebuah perusahaan. Tujuan yang pertama adalah untuk mencapai keuntungan maksimal. Tujuan yang kedua adalah ingin memakmurkan pemilik perusahaan atau para pemilik saham. Sedangkan tujuan perusahaan yang ketiga adalah memaksimalkan nilai perusahaan yang tercermin pada harga sahamnya. Ketiga tujuan perusahaan tersebut sebenarnya secara substansial tidak banyak berbeda. ( $\mathrm{Dj} \&$ Suarjaya, 2012).

Berdasarkan tujuan yang telah disebutkan, tujuan dari sebuah entitas bisnis adalah meningkatkan nilai entitas tersebut. Nilai perusahaan merupakan bentuk pencapaian perusahaan yang berasal dari kepercayaan masyarakat terhadap kinerja perusahaan setelah melalui proses kegiatan yang panjang, mulai berdiri sampai dengan saat ini. Meningkatnya nilai perusahaan merupakan sebuah prestasi, karena dapat mensejahterakan pemilik (Mayogi, 2016). Dengan kata lain, perusahaan mengharapkan pertumbuhan secara terus 
menerus untuk mempertahankan kelangsungan hidupnya sekaligus memberikan kesejahteraan kepada para pemegang sahamnya dengan memberikan pengembalian dalam bentuk dividen, sedangkan sehingga kebijakan dividen penting untuk memenuhi harapan pemegang saham terhadap dividen dengan tidak menghambat pertumbuhan perusahaan di sisi lain (Wijaya, Bandi \& Wibawa, 2010).

Kebijakan deviden ini terkait dengan keputusan apakah laba yang diperoleh perusahaan akan dibagikan kepada pemegang saham sebagai deviden atau ditahan dalam bentuk laba ditahan guna pembiayaan investasi di masa yang akan datang (Agus, 2010). Kebijakan dividen yang memenuhi harapan investor, akan membuat investor menanamkan modalnya dengan tujuan untuk meningkatkan kesejahteraan yaitu mengharapkan pengembalian dalam bentuk dividen. Perusahaan juga mengharapkan investor terus menanamkan modalnya agar perusahaan dapat menjalankan kegiatannya sekaligus memberikan kesejahteraan kepada para pemegang sahamnya, sehingga kebijakan dividen penting untuk memenuhi harapan pemegang saham terhadap dividen dengan tidak menghambat kinerja perusahaan. Dengan menerapkan kebijakan dividen yang menguntungkan bagi investor, investor akan tertarik untuk menanamkan modalnya pada perusahaan yang selanjutnya akan meningkatkan nilai perusahaan (Sudana, 2011).

Peningkatan nilai suatu entitas harus dibarengi dengan peningkatan kinerja perusahaan pula (Pongoh, 2013). Kinerja perusahaan merupakan suatu hal yang sangat penting, karena kinerja perusahaan berpengaruh dan dapat digunakan sebagai alat untuk mengetahui apakah perusahaan mengalami perkembangan atau sebaliknya. Ukuran kinerja perusahaan yang paling lama dan paling banyak digunakan adalah kinerja keuangan yang diukur dari laporan keuangan perusahaan. Analisis terhadap laporan keuangan dapat dilakukan dengan cara perhitungan rasio keuangan. Jenis rasio keuangan yang sering digunakan dalam menilai kinerja keuangan perusahaan adalah rasio likuiditas, rasio aktivitas, rasio solvabilitas, rasio profitabilitas dan rasio pasar. (Zuliarni, 2012)

Dalam penelitian kali ini, peneliti menggunakan rasio profitabilitas dalam pengukuran kinerja keuangannya, karena pada umumnya investor jangka pendek dan menengah lebih banyak tertarik kepada kondisi keuangan jangka pendek dan kemampuan perusahan untuk membayar dividen yang memadai. Informasi tersebut dapat diketahui dengan cara yang lebih sederhana yaitu dengan menghitung rasio-rasio keuangan yang sesuai dengan keinginan (Fahmi, 2014). Selain itu, salah satu faktor yang mempengaruhi nilai perusahaan adalah kemampuan perusahaan dalam menghasilkan laba, yang dapat dihitung dengan menggunakan rasio profitabilitas. Dengan penghitungan rasio profitabilitas untuk mengukur kinerja keuangan perusahaan jangka pendek, investor maupun perusahaan dapat mengevaluasi dengan cepat hasil perhitungan yang digunakan untuk pengambilan keputusan pada tahun atau periode selanjutnya.

Selain itu, meningkatkan nilai perusahaan juga dapat melalui implementasi keputusan keuangan, salah satunya adalah dengan keputusan investasi (Muid dan Noerirawan, 2012). Keputusan investasi merupakan keputusan terhadap aktiva apa yang akan dikelola oleh perusahaan (Harjito \& Martono, 2010). Keputusan investasi merupakan keputusan yang paling penting karena berpengaruh secara langsung terhadap besarnya investasi dan aliran kas perusahaan untuk waktu-waktu yang akan datang. Keputusan investasi dapat mempengaruhi nilai perusahaan karena dengan komposisi investasi yang baik akan dapat menarik investor untuk berinvestasi pada perusahaan tersebut (Keown, 2011).

Penelitian terkait pengaruh kinerja keuangan terhadap inilai perusahaan yang dilakukan Sari (Gustini dan Tripermata, 2016) pengaruh signifikan variabel ROA terhadap variabel nilai perusahaan, (Marsha dan Murtaqi, 2017) menemukan bahwa ROA dan Current Ratio memiliki hubungan positif dengan nilai perusahaan, sedangkan Acid Test Ratio memiliki hubungan negatif. Penelitian terkait pengaruh keputusan investasi terhadap nilai perusahaan yang dilakukan Ansori dan H.N. (2010) menunjukkan bahwa keputusan investasi mempunyai pengaruh yang signifikan terhadap nilai perusahaan di Jakarta Islamic Index (Fajaria, Purnamasari dan Isnalita, 2017) yang menemukan bahwa keputusan investasi dan keputusan pendanaan tidak memiliki pengaruh positif yang signifikan terhadap nilai perusahaan. Penelitian terkait pengaruh kinerja keuangan terhadap kebijakan dividen yang dilakukan oleh Ressy dan Chariri (2013) 
menunjukkan bahwa profitabilitas berpengaruh positif terhadap kebijakan dividen. Penelitian terkait pengaruh keputusan investasi terhadap kebijakan dividen yang dilakukan Nur (2017) yang menemukan bahwa keputusan investasi berpengaruh positif dan signifikan baik terhadap keputusan pendanaan maupun kebijakan dividen. Penelitian terkait pengaruh kebijakan dividen terhadap nilai perusahaan yang dilakukan Arifah dan Raifah (2013) menunjukkan bahwa kebijakan dividen memiliki pengaruh positif terhadap nilai perusahaan. Efni (2017) menemukan bahwa kebijakan dividen tidak dapat meningkatkan nilai perusahaan.

Berdasarkan pemaparan di atas, maka sebelum seorang investor menginvestasikan sahamnya terhadap sebuah perusahaan, investor harus terlebih dahulu melihat bagaimana kinerja keuangan dan keputusan investasi yang dilakukan oleh perusahaan. Kinerja keuangan dan kuputusan investasi yang baik, salah satunya dapat dilihat dari kebijakan dividen yang diterapkan perusahaan untuk mempertahankan dan menarik para investor agar mau berinvestasi pada perusahaan tersebut. Dengan adanya kebijakan dividen yang diterapkan secara baik, maka nilai perusahaan juga akan semakin baik. Oleh karena itu, penulis tertarik untuk melakukan penelitian mengenai bagaimana pengaruh kinerja keuangan dan keputusan investasi terhadap nilai perusahaan dengan kebijakan dividen sebagai variabel intervening.

Kerangka konseptual dalam penelitian ini adalah sebagai berikut :

Gambar 1. Kerangka Konseptual

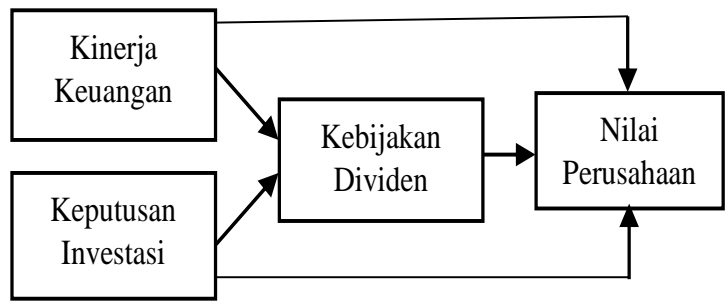

Dan diperoleh hipotesis sebagai berikut:

H1 : Diduga kinerja keuangan berpengaruh terhadap nilai perusahaan.

H2 : Diduga keputusan investasi berpengaruh terhadap nilai perusahaan.

H3 : Diduga kinerja keuangan berpengaruh terhadap kebijakan dividen.

H4 : Diduga keputusan investasi berpengaruh terhadap kebijakan dividen.

H5 : Diduga kebijakan dividen berpengaruh terhadap nilai perusahaan.

H6 : Diduga kinerja keuangan berpengaruh terhadap nilai perusahaan melalui kebijakan dividen.

H7 : Diduga keputusan investasi berpengaruh terhadap nilai perusahaan melalui kebijakan dividen.

\section{METODE PENELITIAN}

Jenis penelitian yang akan dilakukan oleh peneliti berupa penelitian kuantitatif dengan pendekatan deskriptif. Penelitian ini bertujuan untuk menguji variabel dependen yaitu nilai perusahaan dengan kebijakan dividen sebagai variabel intervening terhadap variabel independen, yaitu kinerja keuangan periode 2013-2017. Populasi dalam penelitian ini adalah perusahaan sektor industri dasar dan Tabel 1. Sampel Penelitian kimia yang terdaftar dalam BEI periode tahun 2013-2017 dengan jumlah 74 perusahaan. Sampel dari penelitian ini berjumlah 13 perusahaan. Teknik pengambilan sampel dari penelitian ini adalah teknik sampling purposive, yaitu teknik penentuan sampel dengan pertimbangan tertentu. Perusahaan-perusahaan yang menjadi sampel dalam penelitian ini adalah:

\begin{tabular}{ccc}
\hline No & Kode Saham & Nama Emiten \\
\hline 1. & INTP & Indocement Tunggal Prakasa Tbk \\
2. & SMBR & Semen Baturaja Tbk \\
3. & SMGR & Semen Indonesia (Persero) Tbk \\
4. & AMFG & Asahimas Flat Glass Tbk \\
5. & ARNA & Arwana Citramulia Tbk \\
6. & TOTO & Surya Toto Indonesia Tbk \\
7. & INAI & Indal Aluminium Industry Tbk \\
\hline
\end{tabular}

DOI: DOI: 10.26858/jekpend.v2i2.9369 
Dea Agustin Adrianingtyas, Agus Sucipto, Pengaruh Kinerja Keuangan... $\mid 26$

\begin{tabular}{ccc}
\hline 8. & LION & Lion Metal Works Tbk \\
9. & LMSH & Lionmesh Prima Tbk \\
10. & DPNS & Duta Pertiwi Nusantara Tbk \\
11. & EKAD & Ekadharma International Tbk \\
12. & TRST & Trias Sentosa Tbk \\
13. & CPIN & Charoen Pokphand Indonesia Tbk \\
\hline
\end{tabular}

Variabel Penelitian

a. Variabel Independen

Variabel independen adalah variabel yang mempengaruhi atau yang menjadi sebab perubahannya atau timbulnya variabel dependent (Sugiyono, 2013:59). Dalam penelitian ini, variabel independen yang digunakan adalah kinerja keuangan dan keputusan investasi.

b. Variabel Dependen

Variabel dependen adalah variabel yang dipengaruhi tau yang menjadi akibat karena adanya variabel bebas (Sugiyono, 2013:59).
Dalam penelitian ini variabel dependen yang digunakan adalah nilai perusahaan.

c. Variabel Intervening

Menurut Sugiyono (2013:61) variabel intervening adalah variabel yang terletak diantara variabel independen dan dependen, sehingga variabel independen secara tidak langsung mempengaruhi berubahnya atau timbulnya variabel dependen, yang disimbolkan dengan simbol (Y). Dalam penelitian ini variabel intervening yang digunakan adalah kebijakan dividen yang menghubungkan antara variabel independen yaitu kinerja keuangan dan keputusan investasi dengan variabel dependen yaitu nilai perusahaan.

HASIL DAN PEMBAHASAN

Hasil Analisis Regresi Substruktur 1 dan Substruktur 2

Substrusture 1

Tabel 2. Hasil Uji Koefisien Determinasi Model 1

\begin{tabular}{lrrrr}
\multicolumn{5}{c}{ Model Summary } \\
\hline Model & R & R Square & Adjusted R Square & Std. Error of the Estimate \\
\hline 1 & $.570^{\text {a }}$ & .325 & .303 & .03752
\end{tabular}

a. Predictors: (Constant), PER, ROA

Pada tabel uji koefisien detreminasi diatas nilai $\mathrm{R}$ square atau koefisien determinasi sebesar 0,325 menunjukan bahwa variasi kebijakan dividen dapat dijelaskan oleh variabel profitabilitas dan price to earning ratio sebesar Tabel 3. Hasil Uji Regresi Model 1
0,325 . Artinya variabel profitabilitas dan price to earning ratio memiliki pengaruh terhadap struktur modal sebesar $32,5 \%$ dan sisanya $67,5 \%$ dipengaruhi oleh variabel lain yang tidak dimasukan dalam penelitian.

\section{Coefficients $^{\text {a }}$}

\begin{tabular}{|c|c|c|c|c|c|c|}
\hline \multirow[b]{2}{*}{ Mod } & & \multicolumn{2}{|c|}{ Unstandardized Coefficients } & $\begin{array}{l}\text { Standardized } \\
\text { Coefficients }\end{array}$ & \multirow[b]{2}{*}{$\mathrm{t}$} & \multirow[b]{2}{*}{ Sig. } \\
\hline & & $\mathrm{B}$ & Std. Error & Beta & & \\
\hline \multirow[t]{3}{*}{1} & (Constant) & -.017 & .010 & & -1.744 & .086 \\
\hline & ROA & .424 & .081 & .573 & 5.224 & .000 \\
\hline & PER & .000 & .000 & .344 & 3.131 & .003 \\
\hline
\end{tabular}

a. Dependent Variable: DPR

Berdasarkan tabel hasil uji regresi dapat dilihat tingkat signifikan profitabilitas (ROA) sebesar 0,000 yang menandakan tingkat signifikan lebih besar dari taraf nyata $(0,000<$ $0,005)$ maka dapat disimpulkan bahwa variabel profitabilitas berpengaruh signifikan terhadap kebijakan dividen. Besarnya pengaruh dilihat dari angka standardized coefficient sebesar 0,573 atau $57,3 \%$ dan dianggap positif signifikan. Tingkat signifikan variabel Price to 
Earning Ratio (PER) sebesar 0,003 yang menandakan tingkat signifikan lebih besar dari taraf nyata $(0,003<0,005)$ maka dapat disimpulkan bahwa variabel PER berpengaruh signifikan terhadap kebijakan dividen. Besarnya pengaruh dilihat dari angka standardized coefficient sebesar 0,344 atau $34,4 \%$ dan dianggap positif signifikan.

\section{Substruktur 2}

Tabel 4. Hasil Uji Koefisien Determinasi Model 2

Model Summary

\begin{tabular}{lcccr}
\hline Model & $\mathrm{R}$ & R Square & Adjusted R Square & Std. Error of the Estimate \\
\hline 1 & $.297^{\mathrm{a}}$ & .088 & .043 & .32251 \\
\hline a. Predictors: (Constant), DPR, PER, ROA & & \\
\hline
\end{tabular}

Besarnya nilai $\mathrm{R}$ square yang terdapat pada tabel uji koefisien determinasi sebesar 0,088 hal ini menunjukan bahwa sumbangan variabel profitabilitas dan price to earning ratio, dan dividen payout ratio terhadap nilai perusahaan sebesar 8,8\% sementara sisanya 91,2\% merupakan kontribusi dari variabel lain yang tidak dimasukan dalam penelitian.

Tabel 5. Hasil Uji Regresi Model 2

\begin{tabular}{|c|c|c|c|c|c|c|}
\hline \multicolumn{7}{|c|}{ Coefficients $^{a}$} \\
\hline & & Unstandardizec & Coefficients & $\begin{array}{l}\text { Standardized } \\
\text { Coefficients }\end{array}$ & & \\
\hline \multicolumn{2}{|c|}{ Model } & $\mathrm{B}$ & Std. Error & Beta & $\mathrm{t}$ & Sig. \\
\hline \multirow[t]{4}{*}{1} & (Constant) & .542 & .087 & & 6.247 & .000 \\
\hline & ROA & -2.027 & .837 & -.374 & -2.423 & .018 \\
\hline & PER & .000 & .001 & -.127 & -.920 & .361 \\
\hline & DPR & 1.507 & 1.092 & .205 & 1.381 & .172 \\
\hline
\end{tabular}

a. Dependent Variable: PBV

Pada tabel regresi model 2 terlihat nilai signifikansi dari variabel profitabilitas (ROA) sebesar 0,018 menunjukan signifikansi lebih kecil dari taraf nyata $(0,018<0,05)$ yang artinya variabel profitabilitas berpengaruh signifikan terhadap nilai perusahaan. Besarnya pengaruh dilihat dari angka standardized coefficient sebesar $-0,374$ atau $-37,4 \%$ dan berpengaruh negatif. Sedangkan tingkat signifikansi dari variabel Price to Earning Ratio (PER) sebesar 0,361 menunjukan signifikansi lebih kecil dari taraf nyata $(0,361>$ $0,05)$ yang artinya variabel PER tidak berpengaruh signifikan terhadap nilai perusahaan. Besarnya pengaruh dilihat dari angka standardized coefficient sebesar $-0,127$ atau $-12,7 \%$ dan berpengaruh negatif. Kemudian, nilai signifikansi dari variabel Dividend Payout Ratio (DPR) sebesar 0,172 menunjukan signifikansi lebih kecil dari taraf nyata $(0,172>0,05)$ yang artinya variabel DPR tidak berpengaruh signifikan terhadap nilai perusahaan. Besarnya pengaruh dilihat dari angka standardized coefficient sebesar 0,205 atau 20,5\% dan berpengaruh positif.

\section{Pembahasan}

Hasil pengujian pengaruh profitabilitas terhadap nilai perusahaan secara langsung menunjukkan bahwa koefisien jalur sebesar 0,374 mempunyai thitung $=-2,423$ dengan tingkat signifikansi $-0,374$ dan tabel $=1,9990$. Probabilitas sebesar $0,018<0,05$ dan nilai thitung < ttabel, maka dapat disimpulkan bahwa profitabilitas berpengaruh signifikan dengan arah negatif terhadap nilai perusahaan, dengan demikian $\mathrm{H} 0$ ditolak dan maka $\mathrm{H} 1$ diterima. Ketika profitabilitas meningkat, maka nilai perusahaan akan mengalami penurunan. Hasil penelitian ini sejalan dengan yang telah dilakukan oleh Marsha dan Murtaqi (2017) ROA dan Current Ratio memiliki hubungan 
positif dengan nilai perusahaan, sedangkan Acid Test Ratio memiliki hubungan negatif.

Hasil pengujian pengaruh price to earning ratio terhadap nilai perusahaan secara langsung menunjukkan bahwa koefisien jalur sebesar $-0,127$ mempunyai thitung $=-0,920$ dengan tingkat signifikansi 0,361 dan ttabel=1,9990. Probabilitas sebesar 0,361 >0,05 dan nilai thitung < ttabel, maka dapat disimpulkan bahwa price to earning ratio tidak berpengaruh terhadap nilai perusahaan, dengan demikian $\mathrm{H} 0$ diterima dan maka $\mathrm{H} 2$ di tolak. Tinggi rendahnya price to earning ratio tidak berpengaruh terhadap nilai perusahaan. Hasil penelitian ini sejalan dengan yang telah dilakukan oleh Fajaria, Purnamasari dan Isnalita (2017) yang menemukan bahwa keputusan investasi dan keputusan pendanaan tidak memiliki pengaruh positif yang signifikan terhadap nilai perusahaan.

Hasil pengujian pengaruh profitabilitas terhadap kebijakan dividen secara langsung menunjukkan bahwa koefisien jalur sebesar 0,573 mempunyai thitung $=5,224$ dengan tingkat signifikansi 0,000 dan ttabel=1,9983. Probabilitas sebesar $0,000<0,05$ dan nilai thitung > ttabel, maka dapat disimpulkan bahwa kinerja keuangan berpengaruh positif dan signifikan terhadap kebijakan dividen, dengan demikian $\mathrm{H} 0$ ditolak dan $\mathrm{H} 3$ diterima. Semakin tinggi profitabilitas, semakin besar jumlah dividen yang akan dibagikan. Hasil penelitian ini sejalan dengan yang dilakukan Penelitian yang dilakukan Zaman (2018), Ressy dan Chariri (2013), Kajola (2015), Sabri, Deviyanti, Kurniawan (2017) menemukan variabel profitabilitas memiliki pengaruh posistif terhadap kebijakan dividen.

Hasil pengujian pengaruh price to earning ratio terhadap kebijakan dividen secara langsung menunjukkan bahwa koefisien jalur sebesar 0,344 mempunyai thitung $=3,131$ dengan tingkat signifikansi 0,003 dan ttabel $=1,9983$. Probabilitas sebesar $0,003<0,05$ dan nilai thitung > ttabel, maka dapat disimpulkan bahwa price to earning ratio berpengaruh positif dan signifikan terhadap kebijakan dividen, dengan demikian $\mathrm{HO}$ ditolak dan $\mathrm{H} 4$ diterima. Semakin tinggi price to earning ratio maka semakin bagus kebijakan dividen. Hasil penelitian ini sejalan dengan yang telah dilakukan oleh Nur (2017) dimana keputusan investasi berpengaruh positif terhadap kebijakan dividen, karena dengan dilakukannya investasi maka perusahaan akan semakin profitable, dan akan semakin meningkatkan jumlah dividen yang dibayarkan.

Hasil pengujian pengaruh kebijakan dividen terhadap nilai perusahaan secara langsung menunjukkan bahwa koefisien jalur sebesar 0,205 mempunyai thitung $=1,381$ dengan tingkat signifikansi 0,172 dan ttabel $=1,9990$. Probabilitas sebesar 0,172 $>0,05$ dan nilai thitung < ttabel, maka dapat disimpulkan bahwa kebijakan dividen tidak berpengaruh signifikan terhadap nilai perusahaan, dengan demikian $\mathrm{H} 0$ diterima dan H5 ditolak. Tinggi rendahnya kebijakan dividen tidak berpengaruh terhadap nilai perusahaan. Hasil penelitian ini sejalan dengan yang telah dilakukan oleh penelitian yang dilakukan oleh Efni (2017) menemukan bahwa kebijakan dividen tidak berpengaruh nilai perusahaan.

Hasil pengujian pengaruh langsung profitabilitas terhadap kebijakan dividen adalah sebesar 0,573. Sedangkan pengaruh tidak langsung profitabilitas terhadap nilai perusahaan melalui kebijakan dividen diperoleh dengan cara perkalian antara nilai beta profitabilitas terhadap nilai perusahaan dengan nilai beta kebijakan dividen terhadap nilai perusahaan yaitu $0,573 \times 0,205=0,117465$. Maka, berdasar perhitungan yang telah dilakukan diperoleh nilai pengaruh langsung sebesar 0,573 dan nilai pengaruh tidak langsung sebesar 0,117465. Hal ini berarti terdapat pengaruh langsung profitabilitas terhadap nilai perusahaan melalui kebijakan dividen. Sehingga H6 diterima, profitabilitas berpengaruh terhadap nilai perusahaan melalui kebijakan dividen.

Hasil pengujian pengaruh langsung price to earning ratio terhadap kebijakan dividen adalah sebesar 0,344. Sedangkan pengaruh tidak langsung price to earning ratio terhadap nilai perusahaan melalui kebijakan dividen diperoleh dengan cara perkalian antara nilai beta price to earning ratio terhadap nilai perusahaan dengan nilai beta kebijakan dividen terhadap nilai perusahaan yaitu $0,344 \times 0,205=$ 0,07052 . Maka, berdasar perhitungan yang telah dilakukan diperoleh nilai pengaruh langsung sebesar 0,344 dan nilai pengaruh tidak langsung sebesar 0,07052. Hal ini berarti terdapat pengaruh price to earning ratio terhadap nilai perusahaan melalui kebijakan dividen. Sehingga $\mathrm{H} 7$ diterima, price to earning ratio berpengaruh terhadap nilai perusahaan melalui kebijakan dividen. 


\section{SIMPULAN DAN SARAN}

\section{Simpulan}

1. Kinerja keuangan memiliki pengaruh yang signifikan dan negatif terhadap nilai perusahaan.

2. Keputusan investasi tidak memiliki pengaruh terhadap nilai perusahaan.

3. Kinerja keuangan memiliki pengaruh yang positif dan signifikan terhadap kebijakan dividen.

4. Keputusan investasi memiliki pengaruh signifikan terhadap kebijakan dividen.

5. Kebijakan dividen tidak memiliki pengaruh terhadap nilai perusahaan.

6. Kinerja keuangan berpengaruh secara signifikan terhadap nilai perusahaan melalui kebijakan dividen.

7. Keputusan investasi berpengaruh secara signifikan terhadap nilai perusahaan melalui kebijakan dividen.

\section{Saran}

1. Bagi investor, sebelum memutuskan untuk berinvestasi pada saham industri tertentu hendaknya investor tidak hanya mengacu kepada rasio keuangan perusahaan saja namun juga pada faktor eksternal perusahaan seperti tingkat kurs dan kondisi perekonomian negara. Karena selain faktor internal perusahaan faktor eksternal merupakan salah satu faktor penting yang harus diperhatikan dalam membuat keputusan investasi.

2. Bagi penulis selanjunya, dengan keterbatasan variabel yang peneliti lakukan hendaknya penelitian selanjutnya dapat meneliti pada objek lain atau menambah variabel baru sehingga pengaruh antar variabel menjadi semakin tinggi.

\section{DAFTAR RUJUKAN}

Abdul Muid, Moch. Ronni Noerirawan, 2012. "Pengaruh Faktor Internal dan Eksternal Perusahaan Terhadap Nilai Perusahaan". Jurnal Akuntansi, 1 (2).

Agus Harjito dan Martono. 2010. Manajemen Keuangan. Yogyakarta: Ekonisia.

Agus, R. Sartono. 2010. Manajemen Keuangan Teori dan Aplikasi. Edisi. Keempat. Yogyakarta: BPFE.

Ansori, Mochamad dan H.N, Denica. (2010). Pengaruh Keputusan Investasi Keputusan Pendanaan Dan Kebijakan Dividen Terhadap Nilai Perusahaan pada Perusahaan yang Tergabung dalam
Jakarta Islamic Index Studi Pada Bursa Efek Indonesia (BEI), Analisis Manajemen, 4 (2), 153-175.

Arifah dan Raifah. (2013). The Effect of Investment Decision, Funding Decision and Dividend Policy on Corporate Value, 1-7.

Dj, Alfredo Mahendra, Artini, Luh Gede Sri, Suarjaya, A.A Gede. (2012). Pengaruh Kinerja Keuangan Terhadap Nilai Perusahaan pada Perusahaan Manufaktur di Bursa Efek Indonesia. Jurnal Manajemen, Strategi Bisnis dan Kewirausahaan, 6 (2), 130-138.

Efni. (2017). The Mediating Effect of Investment Decisions and Financing Decisions on the Effect of Corporate Risk and Dividend Policy against Corporate Value, Investment Management and Financial Innovations, 14 (2), 27-37.

2014. Manajemen Keuangan Perusahaan dan Pasar Modal. Jakarta: Mitra Wacana Media.

Keown, Arthur J., dkk. 2011. Manajemen Keuangan: Prinsip \& Penerapan. Jakarta: PT. Indeks.

Marsha, Nadya dan Murtaqi, Isrochmani. (2017). The Effect Of Financial Ratios On Firm Value in The Food And Beverage Sector Of The IDX, Journal Of Business And Management, 6 (2), 214226.

Mayogi, Dien Gusti. 2016. Pengaruh Profitabilitas, Kebijakan Dividen, dan Kebijakan Hutang terhadap Nilai Perusahaan. Jurnal Ilmu dan Riset Akuntansi, 5, (1).

Nur (2017). Keterkaitan Keputusan Investasi, Keputusan Pendanaan dan Kebijakan Dividen pada Perusahaan Manufaktur di Indonesia, Jurnal Manajemen Bisnis Indonesia, 4 (3), 409-425.

Pongoh, Marsel. (2013). Analisis Laporan Keuangan untuk Menilai Kinerja Keuangan PT. Bumi Resources Tbk. Jurnal EMBA, 1 (3), 669-679.

Ressy, Aggy Eka dan Anis Chariri. (2013). Pengaruh Kinerja Keuangan Terhadap Kebijakan Dividen di Bursa Efek Indonesia, Diponegor Journal of Accounting, 2 (4), 1-10.

Sari, Diah Manda, Emilia Gustini dan Lukita Tripermata. (2016). Pengaruh Struktur Modal dan Kinerja Keuangan Terhadap 
Nilai Perusahaan pada Perusahaan Perbankan di Bursa Efek Indonesia. Jurnal Ilmiah Global Masa Kini, 7 (3), 33-39.

Sudana, I Made. 2011. Manajemen Keuangan Perusahaan: Teori dan Praktik. Jakarta: Erlangga.

Sugiyono. 2013. Metode Penelitian Pendidikan Pendekatan Kuantitatif Kualitatif, dan R \& D. Bandung: Alfabeta.

Wijaya, L.R.P, Wibawa, A. (2010). Pengaruh Keputusan Investasi, Keputusan Pendanaan, dan Kebijakan Dividen Terhadap Nilai Perusahaan. Nasional Akuntansi XIII Purwokerto.

Zuliarni, Sri. (2012). Pengaruh Kinerja Keuangan Terhadap Harga Saham Pada Perusahaan Mining and Mining Service di Bursa Efek Indonesia (BEI). Jurnal Aplikasi Bisnis, 3 (1). 